\title{
INTRODUCING IMPORTANT CHANGES CONCERNING THE AVOIDANCE OF DOUBLE TAXATION between Czech Republic and Poland
}

\author{
Adam Świerczek ${ }^{1}$ \\ The Law Firm HAJDUK \& PARTNERS s.r.o. \\ email: adam.swierczek@hajduk.cz
}

ŚWIERCZEK, Adam. Introducing important changes concerning the avoidance of double taxation between Czech Republic and Poland. International and Comparative Law Review, 2014, Vol. 14., No. 2, pp. 83-92. DOI: 10.1515/iclr-2016-0053.

\begin{abstract}
On January 1, 2013 a new treaty between the Czech Republic and the Republic of Poland dealing with avoidance of double taxation as well as prevention of tax evasion in the field of income tax has come into effect. The treaty newly introduced the taxation of income of the permanent establishment, changes in rates of dividend taxes, interest rates and royalties, and, last but not least, what has been altered is even the definition of royalties. Furthermore, the treaty also brings a new adaptation of the profits of associated enterprises. Approval of the clause regarding exchange of information as well as cancellation of the tax-sparing clause is a novelty. This article is dealing with the description of the changes and novelties and the indication of the potential importance.
\end{abstract}

Keywords: avoidance of double taxation, treaty with the Republic of Poland, the permanent establishment, dividend taxes, interest and royalties, the associated enterprises

\section{Introduction}

On September 13, 2011 in Warsaw a treaty was signed between the Czech Republic and the Republic of Poland dealing with avoidance of double taxation as well as prevention of tax evasion in the field of income tax (hereinafter referred to as "new treaty"). Following successful ratification in both countries, this treaty has come into effect since January 1, 2013, which has substituted a treaty between the government of the Czech Republic and the government of the Republic of Poland on avoidance of double taxation in terms of income and property tax of the year of 1993 (hereinafter referred to as "old treaty") ${ }^{2}$. As the Senate of the Czech Republic stated, "possible double taxation is undesirable for

1 Practicing lawyer and Ph.D. student, Czech Republic.

2 Notification of the Ministry of Foreign Affairs regarding the negotiation of an Treaty between the Czech Rep. and the Republic of Poland of limiting double taxation and preventing tax evasion in the field of income tax. Referenced in: Collection of International Treaties of the Czech Republic. 2012, chapter 55, p. 2122-2168. 
it lowers the income of individuals or legal entities of one country originating in the other. Because the reason for the occurrence of international double taxation is colliding tax law of the two countries, such taxation can be effectively reduced by means of measures mutually regulated by an international tax treaty."3

This article focuses on cardinal novelties and changes that have been introduced into the Czech legal system specifically in connection with the application of the treaty regarding the prevention of double taxation between the Czech Republic and Poland which has been in operation for over one year.

The new treaty, published in the Collection of International Treaties N. 102/2012, reacts accordingly to developing economies of the Czech Republic and Poland as well as their mutual trade, investments and a variety of forms of international cooperation. It also takes into account the membership of both countries in the European Union. As far as content is concerned, this treaty is inspired by the Model treaty of the Organization for Economic Cooperation and Development, hereinafter referred to as OECD) which presents a general norm, guidelines as to the form of such type of treaties; one positive fact needs to be emphasized that in spite of strong influence of the OECD's recommendation, it does not neglect to take into consideration the specific nature of cooperation of the Czech Rep. and the Republic of Poland. Another source of inspiration has been a model treaty of the United Nations organization (UN). Since the treaty nations expect income from objective legal regulations of tax from individual sources of income between both countries, i.e. between the country of the source of income and the country of its recipient.

The treaty relates materially to income taxes deposited by the name of each contractual country while wherein what is considered as income tax is all taxes collected from overall income or a part of income, including tax of profit from alienation of movable or real estate, tax from overall sum of wages or salary paid by businesses as well as tax from property accrual. From a personal point of view, the Treaty concerns persons who are residents of one or both of the contractual countries.

\section{Elementary excursus on principles introduced by Treaty}

With the progress of the times and the change of the political and economical relationships, the 1993 treaty began to be considerably inappropriate as it lost the ability to regulate situations resulting from the socio-economical changes. The 1993 treaty, or more precisely its creators, could not predict the development

3 Senate of the Parliament of the Czech Republic. The Governmental draft to be submitted to the Parliament of the Czech Republic's Consent to the ratification of the the Treaty between the Czech Republic and Poland for the avoidance of double taxation and prevention of fiscal evasion with respect to taxes on income, signed in Warsaw on 13 September,2011. Prague: Senate of the Parliament of the Czech Republic, (C2011 [vid. 2014-03-31]. Available at: http://www.senat.cz/xqw/webdav/pssenat/original/62278/52689. 
and state of the both of the concerned countries in the recent years. On both sides of the common border, there has arisen a need to introduce new corrections in certain areas of the tax policies while such a generally stated claim has been reflected in certain alterations introduced with the new treaty, namely in taxation of permanent establishment, changes in rates of dividend taxes, interest rates and royalties, and, last but not least, what has been altered is even the definition of royalties. Furthermore, the treaty also brings a new adaptation of the profits of associated enterprises. Approval of the clause regarding exchange of information as well as cancellation of the tax-sparing clause is a novelty. In the case of permanent establishment, the definition of the formation of "tied permanent establishment" has been registered. ${ }^{4}$

Individual changes and their practical impact will have been elaborated on in the following paragraphs, while it is necessary to realize that here there is no mention of all types of income whose taxation is regulated by the new treaty. ${ }^{5}$

\section{Taxation of services}

The first important alteration is the introduction of the possibility of forming a permanent establishment which does not constitute a legal entity. Although a tendency might arise to take a term specified in the treaty for an adaptation of permanent establishment known from the national law, the matter is not about identical issue. Specifying the issues within the treaty is meant to determine when the contractual country is entitled to tax the income of a company from the other contractual country. ${ }^{6}$ This is directed specifically at tax subjects that, for instance, generate income within the Czech Republic even though they are not its tax residents. For the new treaty to come into effect could be possible, and it of course happened that foreigners made an income in the Czech Rep.

4 Both positive as well as negative determination of the concept of "permanent establishment" for the purposes of international treaty is provided in article 5 of the new treaty as it constitutes a permanent location of work where a part or all of the business activity is performed (i.e. headquarters, factory, office, warehouse, etc.; by contrast as a permanent establishment it is impossible to consider facilities used primarily for the purposes of storage, exhibition or provision of the given business's goods). It is necessary to add that the new treaty contains its own definition of a permanent establishment while it must be given priority to the definition of a permanent establishment used by national regulations. Additionally, the judgment of the Municipal Court of Prague Act N. 10a39/2004-97, which contains a statement that if an international double-taxation reduction treaty regulates the state of a permanent establishment differently from the Czech Republic, first of all, it is necessary to conform to a proper international treaty on reduction of double taxation and then the Czech law.

5 The list of types of income must include income from independent professions, income from performing dependent activities, pension and income from performing public functions, as well as income from real estate, profits from alienated properties.

6 Judgment of the Supreme Administrative Court of November 22, 2007, Act N. 9 Afs 85/2007 - 76 [online]. Available at www.nssoud.cz. 
despite not paying due taxes to the State Treasury, which may be understood as at least unfair. The new treaty has reacted to such a situation instating permanent establishment which can mean an office or warehouse of a Polish citizen or a Polish company also in case when services of the Polish citizen are offered without a permanent seat within the Czech Republic. I am emphasizing the issue of permanent establishment was regulated in the old treaty; however, the new one has been extended by the area of services. It is a matter of an exception from a principle stating that the incomes of one contractual country are taxed only in the given country.

The new treaty stipulates that a permanent establishment is set up as long as a business of one contractual country offers services, including advisory or managerial services, and the activity of such nature takes place within the other contractual country for one or more periods exceeding the total of six months in any 12-month period. Six months are understood as 183 days. On the other hand, it is not by any chance the issue of a one-time or temporary offer of services. It is also interesting that a period of six months is generally considerably short in comparison with other treaties that concern double taxation when in a great number of cases there appears a need to set up a permanent premise following a much longer period of time. ${ }^{7}$ Such an evidently short period is most probably a reflection of frequency of relationships between both countries while even such a short period is sufficient for specific needs. Once the stipulated conditions are fulfilled, a foreign person is required to pay taxes from the income made by the given permanent establishment to the country within which the permanent establishment is located - and not to the country where the business seats are.

The concept of a permanent establishment has turned up especially with the purpose for businesses' incomes not to be taxed in both countries, but only in one. In my opinion one other clear motive has been the element of fair trade when only the country within whose territory foreign persons make profits evidently should have the right to share in the success of the foreign persons who were contributed by the favorable economical-legislative environment designed for enterprises created by its policies.

\section{Changes of deduced tax rates}

Apart from decreasing the rates of income tax from dividends and interests, the new treaty has also stipulated an increase of the rates of income tax from license fees. Taxation of dividends, interests and license fees is in fact divided between both contractual countries, nonetheless in the country of the source of income it must not exceed the limit determined in art. 10, 11 and 12 of the

7 Vyškovská Magdaléna. Interpretation of treaties to limit double taxation in the light of judicial decision of the Supreme Administrative Court and Conseil d'Etat. Praha: Wolters Kluwer ČR, a.s., 2010, 200 p., p. 56. 
Treaty. Certain types of interests, as stated below, are not subject to taxation notwithstanding.

\section{a) Dividends ${ }^{8}$}

In the case of dividends, tax is deduced by the company before it pays a given sum to the rightful person. According to Art. 10 of the new treaty, dividends paid to a company that is a resident of one contractual country, a resident of the other contractual country, can be taxed in the other country. The treaty further adds that dividends may be taxed in the country whose resident is the paying company, though under certain following circumstances that are aimed at limiting the rate.

According the previous treaty, the imposed tax from dividends imposed by a country whose resident is the paying company should not exceed $5 \%$ of gross amount of the dividends provided that the recipient is a company that has $20 \%$ shares of the company that pays the dividends. In all other cases it should not exceed $10 \%$ of gross amount of the dividends. The new treaty does no longer include the above-mentioned varied rate, but introduces one maximum rate of $5 \%$ of total amount of the dividends.

In relation to that there appears a question of taxation of dividends paid out by a daughter company to its mother company abroad. In such a case and in accordance with the European legislature, it comes down to tax exemption.

\section{b) Interests ${ }^{9}$}

Also in the case of interests there may appear a question as to in what country they would be taxed - whether in the one where the source of interest is its resident or, on the other hand, in the one where the recipient is a resident. The treaty in Art. N. 11 stipulates that interests sourcing out of one contractual country and paid out to a resident of the other contractual country may be taxed in the latter of the two countries. Similarly as with dividends, interests may be taxed in the country where the recipient is a resident of as the treaty stipulates the limits of rates. According to the previous treaty the deposited interest tax could not have

8 The new treaty in Art. N. 10, chapter 3 includes its own definition of dividends which constitute "the incomes from shares or other obligations with the exception of claims, including profit-sharing as well as other incomes that are subject to the same tax mode as income from shares in accordance with the legal system of the country whose resident is the company that makes the payment.

9 In Art. N. 11 chapter 3 of the new treaty it is stated that interests are understood as "incomes from claims of any type be they secured or non-secured by the mortgage law with respect to real estate and having or not the right of share in the debtor's income, and especially income from government securities and income from obligations or bonds, including premiums or winnings which are associated with those securities, obligations or bonds. Penalties deposited for late payment are not considered as interests for purposes of the new treaty." 
exceeded $10 \%$ of gross amount of the interests. The new treaty has lowered the limitation to $5 \%$ of gross amount of interests.

It is also worth mentioning that the stated is not validated without exception. Interests are always taxed in the country of origin provided that interests of loan offered by a bank are concerned, furthermore provided that interests paid to the government of the other country or interests paid to residents of the other country are concerned which had been guaranteed by the government of the other country.

\section{c) Royalties ${ }^{10}$}

In the case of royalties constituting income as well, formulation of a basic rule is not an exception, a rule which states that royalties originating in one contractual country and paid out to a resident of the other contractual country may be taxed in the latter. The treaty also approves of the possibility of taxation in the country of origin as long as thus deposited tax does not exceed $10 \%$ of gross amount of royalties.

In contrast to the dividend and interest rates, the rate of income tax has been increased in the new treaty. According to the previous treaty, the amount of deposited tax had not exceeded $5 \%$ of gross amount of royalties. The new treaty has moved the limit to $10 \%$ of gross amount of royalties without distinguishing the types of royalties.

The intention of the contractual countries has been to eliminate obstacles in the flow of capital between the Czech Republic and Poland as well as to boost trade.

\section{New definition of royalties ${ }^{11}$}

The definition of royalties included in Art. N. 12 chapter 3 of the previous treaty had not made it possible, especially within the framework of copyright, to approve of claims in terms of license of computer software for author's fees in the area of art. A number of administrative judgments expresses an opinion that a computer program cannot be considered as literary, artistic nor scientific work.

10 In the treaty royalties are understood as "payments of any type received as compensation for usage or for the right of usage of any copyright, film or frequencies utilized for radio or television broadcasting purposes, patents, registered trademarks, designs or models, plans, secret samples or procedure or any industrial, trade or scientific utility or for information which are relevant to experience gained in the field of industry, trade or science."

11 The new treaty in Art. N. 12 Chapter 3 understands royaltiess as payments of any kind received as compensation of usage or the right of usage of any copyright, film or frequencies used for radio or television broadcast, patents, trademarks, design or model, plan, covert mock-up or procedure or any industrial, trade or scientific facility or information which is relevant to experience gained the field of industry, trade or science.

\section{(c) Palacký University Olomouc, Czech Republic, 2014. ISSN 1213-8770 (print), ISSN: 2464-6601 (online).}


In order to cover income tax from royalties for computer programs it has been necessary to modify the definition of royalties. The definition of royalties in the new treaty does not insist on comprehensive listing of rights which, in terms of royalties, are considered royalties. Therefore subjects of royalties are also the licenses of computer programs. Since January 1, 2013, this type of claims is related to income tax in the amount not exceeding $10 \%$ of gross amount of the royalties.

The primary purpose of the change of the definition of royalties has thus been to impose a license-fee tax for computer programs. ${ }^{12}$

\section{Associated enterprises' income adjustment}

At this point it is appropriate to point out what is meant by the term of associated enterprises. The definition is executed if a business, or enterprise, of one contractual country directly or indirectly shares in management, control or capital of another enterprise of the other contractual country, or if the persons directly or indirectly share in management, control or capital of a enterprise of one contractual country and a enterprise of the other contractual country and if in those cases both enterprises are restricted in their trade or financial relationships by conditions they agreed upon or which have been imposed and which are different from conditions negotiated by and between independent enterprises any profit that would be made by one of the enterprises but for those conditions; even if, however, due to those conditions they have not been made - they would be included as income of the enterprise and taxed accordingly. Evidently the regulations are intended against persons and their enterprises joined by capital or in other ways.

This further modification is advantageous for enterprises operating both in the Czech Republic as well as in Poland. It actually enables one to adjust income in a situation when in one of the countries further assessment of income tax base took place. As it can be inferred from the Senate of the Czech Republic's notice, this modification enables the tax administration to adjust the tax base to an amount which is adequate to objective conditions as long as tax evasion took place by means of covert transfer of profits between enterprises of both contractual countries joined on a capital or personal basis.

Should one contractual country cover profits of this country's enterprise - an tax consequently - the other enterprise's profits that have been taxed in the other

12 As far as the definitions used in the Treaty are concerned, it is valid that should an international double-taxation-limitation treaty not contain a given definition, a definition will be applied which is used in domestic tax law of the contractual country which applies the treaty. Provided that such a definition is included in tax law, it will be given priority over the definition from the Common Law. - Vyškovská Magdaléna. Interpretation of treaties to limit double taxation in the light of judicial decision of the Supreme Administrative Court and Conseil d'Etat. Praha: Wolters Kluwer ČR, a.s., 2010, 200 p., p. 52. 
contractual country, and when the other contractual country agrees that the profits thus covered are the profits which have been achieved by the enterprise of the former country provided that conditions agreed upon by both enterprises have been identical as if they had been agreed upon by independent enterprise, the other contractual country will adjust the imposed tax rate for the profits adequately. (Art. N. 9 Chapter 2 of the Treaty)

\section{Income tax for interests, credits and bank loans}

In many cases interest tax is an obstacle of a free movement in international trade. Because of this issue, the new treaty introduces the exemption from the taxation of credits and bank loans. This will facilitate the access to credits and bank loans which are offered by Czech banks to Polish companies and the Polish banks to Czech companies. As a result this change should help eliminate the obstacles in the transfer of capital between Poland and the Czech Republic. This particular step may be understood as more effort to increase trade.

\section{Elimination of the so-called tax sparing clause}

The tax sparing clause may be understood as some fictitious tax credit. This clause enables the taxpayers to include in the tax paid in one contractual country also the tax which had never been paid in the other contractual country. As a consequence of this, income of a Polish taxpayer coming from another country is taxed at a lower rate, for instance at an effective rate of $9 \%$ instead of the $10 \%$ rate for dividends as is stipulated in the old treaty.

In accordance with OECD recommendations, such a clause should be included only in treaties with countries which are not well-developed in terms of trade. OECD does not forbid to use the clause, but recommends to introduce regulations which would prevent the abuse of it and potential tax evasion.

The goal of the tax sparing clause is to increase a country's attractiveness and to draw foreign investors. The clause basically shows the domestic investors that it is beneficial to invest abroad; therefore the usage of such a clause had been recommended in the case of bilateral treaties between a developed and a developing countries as for investors from a country economically developed it was interesting to direct their investments into a less developed country and thusly support its industrial, trade and scientific development. Several countries included the clause in return for other benefits, such as a lower income tax from dividends, interests and royalties. ${ }^{13}$

Nevertheless according to the Polish government, the clause is not an effective tool to support the economical development of a country. In fact the clause advocates just short-term investments and discourages the long-term invest-

13 Tax sparing A Reconsideration. Paris: OECD Publishing, 1998, 88 p., p. 19. 
ments. Furthermore, the use of it decreases the income of the State Budget what is a reason why, for several years the Polish Ministry of Finance has been attempting to eliminate this clause from all double-taxation treaties. Logically this clause has been dropped from the new treaty with the Czech Republic. The fact that this clause does not belong in double-taxation treaties has a historical background originating from the creation of the clause. The construction of the tax-sparing clause developed in times when the international trade had not been exuberant, the domestic markets were regulated while all of in-coming and outgoing investments were controlled. ${ }^{14}$ As the main goal is to offer foreign financial aid, between the Czech Republic and Poland as two developed countries it seems to be rather unnecessary, hence there is no wonder that this clause has not appeared in the Treaty at all. OECD has even performed the division of ways how taxpayers evaded their tax duties by means of this clause. ${ }^{15}$

\section{New clause of information exchange}

In reference to Art. N. 24 of the new treaty, an information-exchange clause has been introduced. According to it each of the contractual countries may request of the other party to provide information which is relevant in reference to the implementation of the stipulations of this treaty and which refer to all types or names of taxes imposed in the name of the contractual countries or lower or local instances of administration. The objective is to ensure relevant information in order to properly assess taxes for the taxpayers of the contractual countries, even for the purposes of a potential criminal investigation in reference to criminal tax activities. It is necessary to notice that the contractual parties may be requested to provide information which is not in possession of the countries themselves, but taxpayers such as banks or other financial institutions. According to the old treaty in respect to this, the countries could request the other contractual party to provide information concerning taxes specified in the treaty. Also the country asked for aid did not have the obligation to provide the information concerning goods and service taxes. The new treaty has made such an option feasible.

The country which has been requested to provide information has the obligation to arrange and provide requested information even if it does not need such information for its own tax purposes. It means that a country cannot refuse to provide information only because it is not interested in such information.

\section{Conclusion}

The formation of a new treaty between the Czech and Polish Republics on the limitation of double taxation has been enacted exactly in time to reflect the

14 Tax sparing A Reconsideration. Paris: OECD Publishing, 1998, 88 p., p. 21.

15 Such cases are considered: (a) transfer pricing abuse, (b) conduit situation, (c) rating, (d) potential government abuse of tax sparing. 
increasing volume of mutual trade. After all according to the statistics of the Czech Ministry of Foreign Affairs (hereinafter referred to as "MZV CR"), at present Poland, after Germany and Slovakia, is the third most significant trading partner and has replaced Austria on this position. It may be assumed that thusly established tendency will continue in the future. Moreover, as far as the relationship with the Republic of Poland is concerned, apart from export, there appear more complex forms of manufacture and trade cooperation such as assembly, cooperation, creation of consortiums, establishing mutual companies as well as capital participation and cooperation on third markets. ${ }^{16}$ The creation of new Treaty was inevitable. However, for the responsible evaluation of the impact of the novelties contained in the Treaty in practice is too soon.

16 THE MINISTRY OF FOREIGN AFAFAIRS OF THE CZECH REPUBLIC. Poland. Trade and economical cooperation of the Czech Rep. [online]. Prague: Ministry of Foreign Affairs, @2014 [vid. 2014-03-31]. Available at: http://www.mzv.cz/jnp/cz/encyklopedie_ statu/evropa/polsko/ekonomika/obchodni_a_ekonomicka_spoluprace_s_cr.html 